\title{
Age-Related Enhancement of the Slow Outward Calcium-Activated Potassium Current in Hippocampal CA1 Pyramidal Neurons In Vitro
}

\author{
John M. Power, ${ }^{*}$ Wendy W. Wu, ${ }^{*}$ Evgeny Sametsky, M. Mathew Oh, and John F. Disterhoft \\ Department of Physiology, Northwestern University, Chicago, Illinois 60611-3008
}

Aging is associated with learning deficits and a decrease in neuronal excitability, reflected by an enhanced post-burst afterhyperpolarization (AHP), in CA1 hippocampal pyramidal neurons. To identify the current(s) underlying the AHP altered in aging neurons, whole-cell voltage-clamp recording experiments were performed in hippocampal slices from young and aging rabbits. Similar to previous reports, aging neurons were found to rest at more hyperpolarized potentials and have larger AHPs than young neurons. Given that compounds that reduce the slow outward calcium-activated potassium current $\left(\mathrm{s} \mathrm{I}_{\mathrm{AHP}}\right)$, a major constituent of the AHP, also facilitate learning in aging animals, the $\mathrm{sl}_{\mathrm{AHP}}$ was pharmacologically isolated and characterized. Aging neurons were found to have an enhanced $s l_{A H P}$, the amplitude of which was significantly correlated to the amplitude of the AHP ( $r=0.63 ; p<0.001)$. Thus, an enhanced $s l_{\mathrm{AHP}}$ contributes to the enhanced AHP in aging. No differences were found in the membrane resistance, capacitance, or kinetic and voltage-dependent properties of the $s l_{A H P}$. Because enhanced AHP in aging neurons has been hypothesized to be secondary to an enhanced $\mathrm{Ca}^{2+}$ influx via the voltage-gated L-type $\mathrm{Ca}^{2+}$ channels, we further examined the $\mathrm{s}_{\mathrm{AHP}}$ in the presence of an L-type $\mathrm{Ca}^{2+}$ channel blocker, nimodipine (10 $\mu \mathrm{M})$. Nimodipine caused quantitatively greater reductions in the $\mathrm{sl}_{\mathrm{AHP}}$ in aging neurons than in young neurons; however, the residual $\mathrm{s} \mathrm{AHP}_{\mathrm{AH}}$ was still significantly larger in aging neurons than in young neurons. Our data, in conjunction with previous studies showing a correlation between the AHP and learning, suggest that the enhancement of the $\mathrm{S}_{\mathrm{AHP}}$ in aging is a mechanism that contributes to age-related learning deficits.

Key words: slow afterhyperpolarization; aging; L-type $\mathrm{Ca}^{2+}$ channels; whole-cell voltage clamp; current clamp; neuronal excitability; plasticity; nimodipine
Action potentials in hippocampal pyramidal neurons are followed by a post-burst afterhyperpolarization (AHP), which serves to limit further firing in response to sustained excitation in a process known as spike frequency adaptation (accommodation). Reductions in the AHP and accommodation have been observed in neurons from animals trained in various hippocampus-dependent (Moyer et al., 1996, 2000; Thompson et al., 1996b; Oh et al., 2001) and non-hippocampus-dependent tasks (Disterhoft et al., 1986; Coulter et al., 1989; Saar et al., 1998), suggesting that it is a general mechanism to increase neuronal excitability in learning.

The AHP and accommodation are reduced after the acquisition of the hippocampus-dependent trace eyeblink conditioning task in CA1 and CA3 hippocampal pyramidal neurons (Moyer et al., 1996, 2000; Thompson et al., 1996b). These biophysical changes are most likely learning induced, because they are not observed in neurons of pseudoconditioned controls (which receive the same but unpaired stimuli), naive controls, and animals that failed to acquire the task. Furthermore, reductions in the AHP and accommodation return to baseline in $7 \mathrm{~d}$ (Moyer et al., 1996; Thompson et al., 1996b), consistent with the hypothesis that

Received Feb. 4, 2002; revised May 7, 2002; accepted May 10, 2002.

This work was supported by National Institutes of Health Grants AG08796 (J.F.D.), AG17139 (J.F.D.), MH11737 (M.M.O.), and MH11858 (W.W.W.). We thank Dr. David Mogul for his guidance.

*J.M.P. and W.W.W. contributed equally to this study.

Correspondence should be addressed to John F. Disterhoft, Department of Physiology, Northwestern University Medical School, 303 East Chicago Avenue, Chicago, IL 60611-3008. E-mail: jdisterhoft@northwestern.edu.

J. M. Power's present address: Division of Neuroscience, John Curtin School of Medical Research, Australian National University, ACT 2601, Australia.

Copyright (C) 2002 Society for Neuroscience $\quad 0270-6474 / 02 / 227234-10 \$ 15.00 / 0$ the hippocampus functions as an intermediate storage buffer during learning (Cohen and Eichenbaum, 1993; Kim et al., 1995; Disterhoft et al., 1996).

Acquisition of the trace eyeblink conditioned response is impaired in aging animals and aging humans (Thompson et al., 1996a; Weiss et al., 2000; Knuttinen et al., 2001a,b). Interestingly, the AHP and accommodation are enhanced in CA1 neurons from animals at ages that show learning deficits (Landfield and Pitler, 1984; Moyer et al., 1992, 2000). Although many aging animals failed to acquire the trace eyeblink conditioned response (Thompson et al., 1996a), those that did learn also showed a reduction in the AHP (Moyer et al., 2000). This inverse correlation between the AHP and learning has led us to hypothesize that AHP enhancement in aging is a mechanism involved in agerelated learning deficits. Consistent with our hypothesis, drugs that reduce the AHP in vitro have also been shown to improve learning in aging animals (Deyo et al., 1989; Moyer et al., 1992; Kronforst-Collins et al., 1997; Oh et al., 1999; Weiss et al., 2000, Power et al., 2001).

The AHP is mediated by four outward $\mathrm{K}^{+}$currents $\left(I_{\mathrm{C}}, I_{\mathrm{M}}\right.$, $I_{\mathrm{AHP}}$, and $\left.\mathrm{s} I_{\mathrm{AHP}}\right)$, and its time course is modulated by the hyperpolarization-activated current, $I_{\mathrm{h}}$ (Storm, 1990; Maccaferri et al., 1993; Stocker et al., 1999; Oh et al., 2000). Given the kinetics of these currents, previous experiments showing prolonged AHP and enhanced accommodation in aging neurons strongly implicate alterations in the slower currents, particularly the $I_{\mathrm{AHP}}$, in aging (Landfield and Pitler, 1984; Moyer et al., 1992, 2000; Power et al., 2001). The following experiments were undertaken to determine whether the $I_{\mathrm{AHP}}{ }^{-\mathrm{S}} I_{\mathrm{AHP}}$ contributes to the enhanced AHP in aging neurons. 


\section{MATERIALS AND METHODS}

Subjects. Young (2-3 months old) and aging (>36 months old) female New Zealand albino rabbits (Oryctolagus cuniculus) were chosen as subjects. Animal use procedures were approved by Northwestern University's Animal Care and Use Committee, according to the standards of the United States Department of Agriculture.

Slice preparation. Slices were prepared following procedures similar to those described previously (Moyer et al., 1996). Briefly, two bathing solutions were used during the dissection: (1) normal artificial CSF (aCSF) composed of (in mM): $124 \mathrm{NaCl}, 3 \mathrm{KCl}, 1.3 \mathrm{MgSO}_{4}, 1.24$ $\mathrm{NaH}_{2} \mathrm{PO}_{4}, 2.4 \mathrm{CaCl}_{2}, 26 \mathrm{NaHCO}_{3}, 10$ D-glucose, and (2) sucrose-aCSF, containing an equiosmolar concentration of sucrose in place of $\mathrm{NaCl}$. Both normal- and sucrose-aCSF solutions were oxygenated (bubbled with $95 \% \mathrm{O}_{2}-5 \% \mathrm{CO}_{2}$, pH 7.4).

Rabbits were anesthetized with halothane and killed by decapitation. The brain was rapidly exposed in situ, hemisected, removed within $60 \mathrm{sec}$, and immediately immersed in oxygenated ice-cold $\left(<1^{\circ} \mathrm{C}\right)$ sucroseaCSF for $\sim 4 \mathrm{~min}$. Both hippocampi were quickly dissected out, cut into 3-4 mm chunks, and glued onto chilled chambers that were then filled with ice-cold sucrose-aCSF. Transverse slices $(300 \mu \mathrm{M})$ along the dorsalventral gradient of the hippocampus were prepared using Vibratomes (TPI, O'Fallon, MO) and placed in holding chambers filled with normal$\mathrm{aCSF}$ at room temperature $\left(\sim 23^{\circ} \mathrm{C}\right)$ for at least $45 \mathrm{~min}$ before any experiment.

Whole-cell electrodes and solutions. Patch electrodes were made from borosilicate glass using a Sutter Flaming-Brown horizontal puller (P-87; Sutter Instrument Company, Novato, CA) and heat-polished with a Narishige microforge (Model MF-930; Narishige International USA, Inc., East Meadow, NY) to a resistance of 1.5-6.0 M $\Omega$. Three pipette solutions were used and consisted of the following (in mM): (1) $2 \mathrm{~K}-\mathrm{ATP}$, $10 \mathrm{HEPES}$, and $150 \mathrm{KMeSO}_{4}$; (2) $2 \mathrm{~K}$-ATP, $10 \mathrm{HEPES}, 140 \mathrm{KMeSO}_{4}$, and $10 \mathrm{KCl}$; and (3) $2 \mathrm{~K}$-ATP, $10 \mathrm{HEPES}, 130 \mathrm{KMeSO}_{4}$, and $10 \mathrm{KCl}$. The $\mathrm{pH}$ of these solutions was adjusted to 7.25 with $\mathrm{KOH}$; the osmolarity of these solutions was $290 \pm 10 \mathrm{mOsm}$. The results obtained with these solutions were indistinguishable. $\mathrm{MeSO}_{4}{ }^{-}$was used in place of $\mathrm{Cl}^{-}$to reduce the rundown of the AHP current over time (Zhang et al., 1994). The use of $\mathrm{KMeSO}_{4}$ in the electrode solution resulted in a $\sim 10 \mathrm{mV}$ junction potential with respect to the aCSF. This junction potential was measured for every batch of electrode solution according to procedures published by Neher (1992) and was corrected before data acquisition.

Data analysis and cell criteria. Hippocampal neurons were visualized using either a Zeiss Axioskop (Carl Zeiss, Inc., Oberkochen, Germany) or a Leica DM LFS microscope (Leica Microsystems AG, Wetzlar, Germany); both were equipped with a long working distance $40 \times$ water immersion objective and infrared differential interference contrast optics (Dodt and Zieglansberger, 1990; Stuart et al. 1993).

Two data acquisition systems were developed using either LabVIEW (National Instrument, Austin, TX) or $\mathrm{C}++$ Builder (Borland Software Corporation, Scotts Valley, CA) with National Instrument NIDAQ driver. Data were acquired at $5 \mathrm{kHz}$ and filtered at $2 \mathrm{kHz}$ using a low-pass Bessel filter. Whole-cell recording procedures for young and aging neurons were variants of previously published procedures, using a single pipette to "clean" and patch onto the neuron (Blanton et al., 1989). Recordings were made from the soma of visually identified CA1 pyramidal neurons with seal resistances $>1.5 \mathrm{G} \Omega$ before break through into the whole-cell mode. A few cells were labeled with Lucifer yellow to monitor the equilibration between the intracellular milieu and the pipette solution. All measurements were made at least $10 \mathrm{~min}$ after membrane rupture to allow for adequate solution equilibration. Only neurons with series resistance $<15 \mathrm{M} \Omega$, membrane resistance $>60 \mathrm{M} \Omega$, resting potential less than $-60 \mathrm{mV}$, and for current-clamp recordings action potential amplitude $>90 \mathrm{mV}$ from resting potential were included in the data set.

Current-clamp protocols. The AHP was first measured in current-clamp mode to provide a direct comparison for previous studies. Subsequently, the $I_{\mathrm{AHP}}-\mathrm{S} I_{\mathrm{AHP}}$ was pharmacologically isolated and characterized in voltage-clamp mode. Slices were individually transferred to small glassbottom recording chambers and perfused continuously $(\sim 2 \mathrm{ml} / \mathrm{min})$ with oxygenated aCSF heated to $31^{\circ} \mathrm{C}$. Our laboratory has evidence for a dorsal-ventral gradient in excitability within the hippocampus (Sametsky et al., 2001). Thus, slices equally distributed across the septotemporal axis of the hippocampus in both age groups were used for recording. During current-clamp recordings, a membrane potential of neurons was maintained at $-68 \mathrm{mV}$ with either hyperpolarizing or depolarizing current injection, and the AHP was evoked using a 100 msec depolariz- ing current step that reliably elicited a burst of four action potentials. The AHP measurements included the following: peak amplitude of the AHP (calculated as the maximum negative voltage deflection from the baseline potential during the first $250 \mathrm{msec}$ after the current offset), duration of the AHP (measured as the time required for the membrane potential to return to the baseline potential for at least $10 \mathrm{msec}$ after the $100 \mathrm{msec}$ depolarizing current step offset), and integrated area of the AHP (calculated from the current offset for the entire duration of the AHP).

Voltage-clamp protocols. After current-clamp measurements, the $I_{\mathrm{AHP}}-$ $\mathrm{s} I_{\mathrm{AHP}}$ were isolated by bath perfusion of modified aCSF containing the following: $500 \mathrm{~nm}$ tetrodotoxin (TTX) to block $\mathrm{Na}^{+}$current; $2 \mathrm{~mm} \mathrm{CsCl}$ to block inward $\mathrm{K}^{+}$currents and $I_{\mathrm{h}} ; 2 \mathrm{mM}$ 4-aminopyridine (4-AP) to block $I_{\mathrm{A}}$ and $I_{\mathrm{D}} ; 5 \mathrm{~mm}$ tetraethylammonium (TEA) to block $I_{\mathrm{C}}$ and $I_{\mathrm{M}}$; and $100-500 \mu \mathrm{M}$ picrotoxin, and $2 \mathrm{~mm}$ kynurenic acid or $10 \mu \mathrm{M}$ 6-cyano7-nitroquinoxaline-2,3-(1H,4H)-dione (CNQX), and $25 \mu \mathrm{M} \mathrm{D}$-2-amino5-phosphonovaleric acid (D-AP5) to reduce synaptic current. 4-AP and TEA were substituted for equimolar $\mathrm{NaCl}$. To block the L-type $\mathrm{Ca}^{2+}$ influx, nimodipine (dissolved in dimethyl sulfoxide) was added directly to the modified aCSF to achieve the desired concentration. Because nimodipine is light sensitive, all experiments involving nimodipine were performed in near-darkness. For all pharmacological experiments, slices were exposed to the modified medium for 10-20 min before measurements were taken.

Although both the $I_{\mathrm{AHP}}$ and $\mathrm{s} I_{\mathrm{AHP}}$ coexist in CA1 hippocampus, the $I_{\mathrm{AHP}}$ accounts for only $20 \%$ of the AHP in rabbit CA1 pyramidal neurons (Oh et al., 2000). The apamin-sensitive $I_{\mathrm{AHP}}$ has a relatively fast onset $(1-5 \mathrm{msec})$ and a slow offset lasting between 50 and several hundred milliseconds (Sah, 1996; Stocker et al., 1999). In contrast, the decay time constant of the $\mathrm{s} I_{\mathrm{AHP}}$ is $\sim 1.5 \mathrm{sec}$ (Sah, 1996). Therefore, we differentiated the $\mathrm{s} I_{\mathrm{AHP}}$ from the $I_{\mathrm{AHP}}$ by measuring the tail current $1 \mathrm{sec}$ after pulse offset.

The AHP tail current was evoked by a $100 \mathrm{msec}, 50 \mathrm{mV}$ voltage step from a holding potential of $-55 \mathrm{mV}$. This protocol elicited a single, robust, unclamped $\mathrm{Ca}^{2+}$ current followed by the AHP tail current. Although the membrane voltage was not precisely controlled during the depolarizing step because of the gain and space-clamp limitations, voltage control of the AHP tail current was well maintained (Lancaster and Adams, 1986; Constanti and Sim, 1987; Sah and McLachlan, 1991; Zhang et al., 1995). The AHP tail current measurements included the following: peak amplitude, latency to peak amplitude, amplitude of the tail current at $200 \mathrm{msec}, 1 \mathrm{sec}$, and $2 \mathrm{sec}$ after pulse offset, and decay rate. The decay kinetics of the AHP current were determined by measuring the time it took for the current to decay to half of the $200 \mathrm{msec}$ (half decay 200) and $800 \mathrm{msec}$ amplitudes (half decay 800 , which revealed the decay of the $\mathrm{s} I_{\mathrm{AHP}}$ alone). The decay time constant was also determined by fitting a single exponential to the tail current $400-3000 \mathrm{msec}$ after pulse offset.

The voltage dependence and reversal potential of $\mathrm{s} I_{\mathrm{AHP}}$ were examined by holding the neurons at $-55 \mathrm{mV}$, activating the $\mathrm{s} I_{\mathrm{AHP}}$ by a 100 msec, $50 \mathrm{mV}$ voltage step, and then varying the holding potential of the tail current from -45 to $-95 \mathrm{mV}$ (see Fig. $4 A$ ). The voltage-dependence of $\mathrm{s} I_{\mathrm{AHP}}$ activation was assessed by holding the neurons at $-55 \mathrm{mV}$ and varying the amplitude of a $100 \mathrm{msec}$ step potential (see Fig. $3 A$ ). The time dependence of $\mathrm{s} I_{\mathrm{AHP}}$ activation was assessed by holding the neurons at $-55 \mathrm{mV}$ and varying the duration of a $15-20 \mathrm{mV}$ subthreshold activation pulse (see Fig. $3 B$ ).

Data analysis. All statistical analyses were performed using Statview (SAS Institute Inc., Cary, NC). Correlations were tested using Fisher's $r$ to $z$. Age-related differences in amplitudes were tested using ANOVA, unpaired $t$ test, or Mann-Whitney $U$ test as appropriate. The $F$ test was used to test for age-related differences in the variance. Data are reported as the mean \pm SEM.

Drugs. $\mathrm{KMeSO}_{4}$ was purchased from ICN (Aurora, OH); TTX was from Calbiochem (San Diego, CA); D-AP5 and CNQX were from Tocris (Ellisville, MO). All other drugs were purchased from Sigma (St. Louis, MO).

\section{RESULTS}

The age-related differences in the AHP and AHP currents are summarized in Table 1. No difference was observed in the membrane resistance or membrane capacitance between the two age groups. Similar to our previous report (Moyer et al., 1992), aging neurons rested at more hyperpolarized potentials (aging = $-75.9 \pm 1.2 \mathrm{mV}$; young $=-70.2 \pm 1.4 \mathrm{mV} ; p<0.01$ ) and exhibited greater AHP peak amplitudes (aging $=-9.03 \pm 0.64$ 


\begin{tabular}{|c|c|c|c|c|c|c|c|c|c|}
\hline & \multicolumn{3}{|l|}{ Young } & \multicolumn{3}{|l|}{ Aging } & \multicolumn{3}{|c|}{$p$ values } \\
\hline & Mean & SEM & $n$ & Mean & SEM & $n$ & $\mathrm{~T}$ & $\mathrm{~F}$ & $\mathrm{U}$ \\
\hline \multicolumn{10}{|l|}{ Post-burst AHP measures } \\
\hline Amplitude (mV) & -7.21 & 0.45 & 15 & -9.03 & 0.64 & 12 & 0.025 & 0.395 & \\
\hline Area (mV msec) & -11344 & 1588 & 15 & -14106 & 1732 & 12 & 0.252 & & \\
\hline Duration (msec) & 5489 & 622 & 15 & 6009 & 636 & 12 & 0.568 & & \\
\hline Latency (msec) & 96.6 & 20.4 & 15 & 55.5 & 9.7 & 12 & & 0.006 & 0.242 \\
\hline \multicolumn{10}{|l|}{ AHP tail current measures } \\
\hline Peak amplitude (pA) & 374.1 & 36.3 & 18 & 604.7 & 66.2 & 16 & & 0.037 & 0.007 \\
\hline Latency to peak amplitude (msec) & 154.9 & 39.2 & 18 & 92.4 & 26.1 & 16 & 0.205 & & \\
\hline Area $(\mathrm{pC})$ & 468.9 & 57.8 & 17 & 830.8 & 111.2 & 16 & & 0.019 & 0.012 \\
\hline 200 msec amplitude (pA) & 321.6 & 32.9 & 18 & 486.2 & 47.0 & 16 & 0.006 & 0.247 & \\
\hline $1 \mathrm{sec}$ amplitude $(\mathrm{pA})$ & 186.8 & 22.8 & 18 & 325.9 & 39.5 & 16 & 0.004 & 0.059 & 0.006 \\
\hline 2 sec amplitude (pA) & 101.3 & 16.4 & 18 & 206.2 & 30.9 & 16 & & 0.027 & 0.006 \\
\hline Decay tau (msec) & -1814 & 141 & 16 & -2122 & 183 & 16 & 0.193 & & \\
\hline 200 half decay (msec) & 1256 & 127 & 18 & 1559 & 138 & 16 & 0.117 & & \\
\hline 800 half decay (msec) & 1801 & 96 & 18 & 2141 & 92 & 16 & 0.016 & 0.684 & \\
\hline Reversal potential (mV) & -93.88 & 2.53 & 7 & -93.66 & 1.94 & 11 & 0.944 & & \\
\hline Membrane resistance $(\mathrm{M} \Omega)$ & 101.11 & 5.87 & 18 & 103.06 & 6.79 & 16 & 0.828 & & \\
\hline Resting potential (mV) & -70.19 & 1.41 & 20 & -75.87 & 1.23 & 16 & 0.006 & 0.307 & \\
\hline
\end{tabular}

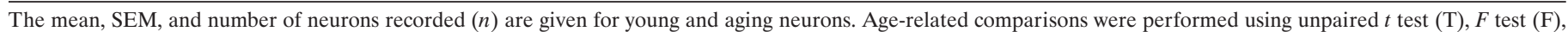
and Mann-Whitney $U$ test $(U)$ as appropriate. Significant effects are highlighted in bold.

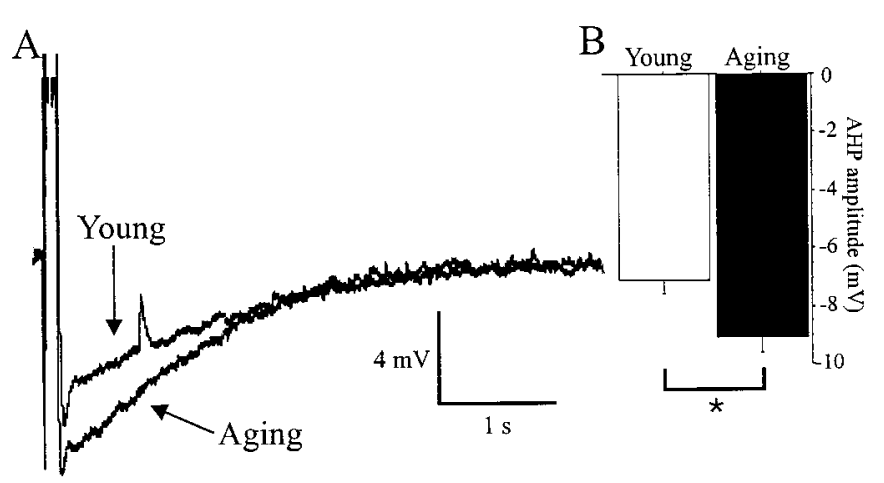

Figure 1. Current-clamp recordings showing an aging-related enhancement of the post-burst AHP. $A$, Voltage traces showing representative AHPs from young and aging neurons. $B$, Mean AHP amplitude was greater in aging neurons than in young neurons (mean \pm SEM; unpaired $t$ test; *p<0.05).

$\mathrm{mV}$; young $=-7.21 \pm 0.45 \mathrm{mV} ; p<0.05)$ (Fig. 1) than young neurons. To control for resting membrane potential (RMP) differences, the neurons were maintained at $-68 \mathrm{mV}$ with either hyperpolarizing or depolarizing current injection, and the AHP was measured after a $100 \mathrm{msec}$ current step that triggered four action potentials. The current used to hold the neurons at -68 $\mathrm{mV}$ was greater for aging neurons than for young neurons (aging $=64 \pm 18 \mathrm{pA}$; young $=6 \pm 15 \mathrm{pA} ; p<0.05)$. Similarly, the current required to elicit four action potentials was greater for aging than for young neurons (aging $=966 \pm 98 \mathrm{pA}$; young $=$ $682 \pm 52 \mathrm{pA} ; p<0.01)$.

The current-clamp measurements of the AHP may be biased by differences in the depolarizing current pulse that may result in differences in $\mathrm{Ca}^{2+}$ influx or subtle changes in other conductances that control spike broadening. Therefore, we characterized the currents underlying the slow AHP $\left(I_{\mathrm{AHP}}-\mathrm{s} I_{\mathrm{AHP}}\right)$ with voltage-clamp protocols in the presence of $\mathrm{Na}^{+}$and $\mathrm{K}^{+}$channel blockers (TTX, CsCl, 4-AP, and TEA). Recordings of the AHP current also revealed an aging-related increase in the peak current amplitude (mixed $I_{\mathrm{AHP}}-\mathrm{S} I_{\mathrm{AHP}}$ amplitude; aging $=604.7 \pm$ $66.2 \mathrm{pA}$; young $=374.1 \pm 36.3 \mathrm{pA} ; p<0.01$ ), current amplitudes at 1 and $2 \mathrm{sec}$ after pulse offset $\left(\mathrm{s} I_{\mathrm{AHP}}\right.$ amplitudes; $1 \mathrm{sec}$ : aging $=$ $325.9 \pm 39.5 \mathrm{pA}$; young $=186.8 \pm 22.8 \mathrm{pA} ; p<0.01 ; 2 \mathrm{sec}$ : aging $=206.2 \pm 30.9 \mathrm{pA}$; young $=106.3 \pm 16.4 \mathrm{pA} ; \mathrm{p}<0.01)$ (Fig. $2 \mathrm{~A}$ ), and integrated area of the tail current (aging $=830.8 \pm$ $111.2 \mathrm{pC}$; young $=486.9 \pm 57.8 \mathrm{pC} ; p<0.01$ ). The amplitude of the AHP showed correlations to all of the amplitude measurements, as well as the integrated area, of the AHP tail current (Table 2), indicating that the enhancements in the $I_{\mathrm{AHP}}$ and the $\mathrm{s} I_{\mathrm{AHP}}$ underlie the enhancement in the AHP in aging.

Most of the amplitude measurements of the $\mathrm{s} I_{\mathrm{AHP}}$ showed a greater variance in aging neurons. Although no differences were observed in the peak latency and the decay of the AHP tail current, the time required for the tail current to decay to half its amplitude at $800 \mathrm{msec}$ after pulse offset was significantly longer in aging neurons than in young neurons $(p<0.05)$. Given that the apamin-insensitive, slow component of the AHP (the $s I_{\mathrm{AHP}}$ ) accounts for $\sim 80 \%$ of the total AHP in rabbit CA1 pyramidal neurons (Oh et al., 2000) and outlasts the $I_{\mathrm{AHP}}$ by seconds (Sah, 1996; Stocker et al., 1999), the correlations between our currentclamp and voltage-clamp measurements suggest that the enhanced $\mathrm{s} I_{\mathrm{AHP}}$ predominantly underlies the enhanced $\mathrm{AHP}$ in aging neurons.

As step potentials were increased, a transient inward current appeared within a few milliseconds of pulse onset, followed by a slow outward current that continued as the AHP tail current. Increasing the amplitude of the step potential increased the amplitude of the $\mathrm{s} I_{\mathrm{AHP}}$ in both age groups. Although no clear-cut threshold of $\mathrm{s} I_{\mathrm{AHP}}$ activation could be determined, no significant tail current was observed unless the step potentials elicited an obvious $\mathrm{Ca}^{2+}$ transient (Fig. $3 A$ ). Increasing the duration of the step potential also increased the amplitude of $\mathrm{s}_{\mathrm{AHP}}$ in both age groups (Fig. 3B). 

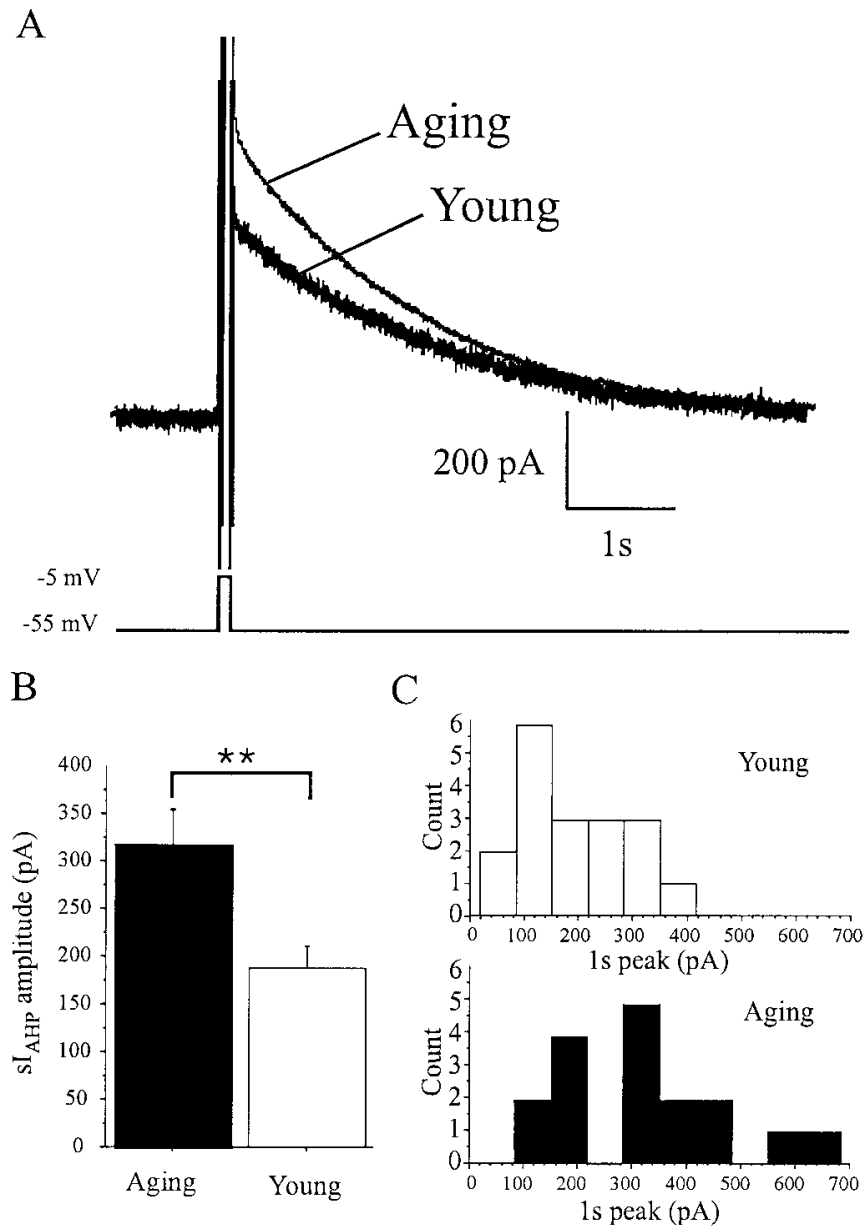

Figure 2. Voltage-clamp recordings showing an age-related enhancement of the $\mathrm{s} I_{\mathrm{AHP}} . A$, Representative $\mathrm{s} I_{\mathrm{AHP}}$ tail currents from young and aging neurons, underlain with the voltage-clamp protocol for evoking the $\mathrm{s} I_{\mathrm{AHP}}$ tail current. $B$, The $\mathrm{s} I_{\mathrm{AHP}}$ amplitude is greater in aging neurons than in young neurons (mean $\pm \mathrm{SEM}$; unpaired $t$ test; ${ }^{* *} p<0.01$ ). $C$, Frequency distribution of the $\mathrm{s} I_{\mathrm{AHP}}(1 \mathrm{sec}$ amplitude) in young and aging neurons.

The kinetics and voltage-dependence of the $\mathrm{s} I_{\mathrm{AHP}}$ were not different in both age groups; these values were consistent with previous recordings from young hippocampal pyramidal neurons (Lancaster and Adams, 1986). The $\mathrm{s} I_{\mathrm{AHP}}$ showed little voltage dependence from -45 to $-85 \mathrm{mV}$ for both age groups (Fig. $4 C$ ). Likewise, its decay rate was voltage independent (Fig. 4B). In both age groups, the $I_{\mathrm{AHP}}$ reversed at approximately $-94 \mathrm{mV}$, suggesting that the enhancement in the $\mathrm{s}_{\mathrm{AHP}}$ in aging was not caused by a change in the driving force for $\mathrm{K}^{+}$.

Our laboratory has reported previously that the AHP enhancement in aging is independent of the resting membrane potential difference (Moyer et al., 1992). Likewise in this study, when we compared the $\mathrm{sI}_{\mathrm{AHP}}$ from cells with comparable resting membrane potentials $(-82 \mathrm{mV}<\mathrm{RMP}<-77 \mathrm{mV})$, aging neurons still had significantly larger $\mathrm{s} I_{\mathrm{AHP}}$ than young neurons (young $=$ $153.63 \pm 22.47 \mathrm{pA}, n=14$; aging $=269.04 \pm 34.64 \mathrm{pA}, n=14$; $p<0.01)$. Thus, the difference in the resting membrane potentials did not contribute to the aging-related enhancement of the $\mathrm{s} I_{\mathrm{AHP}}$.

The $\mathrm{s} I_{\mathrm{AHP}}$ is a $\mathrm{Ca}^{2+}$-dependent $\mathrm{K}^{+}$current. Thus, its amplitude is affected by the amount of $\mathrm{Ca}^{2+}$ available to cause channel activation. Previous reports have demonstrated an aging-related enhancement in voltage-gated $\mathrm{Ca}^{2+}$ influx (Landfield and Pitler,
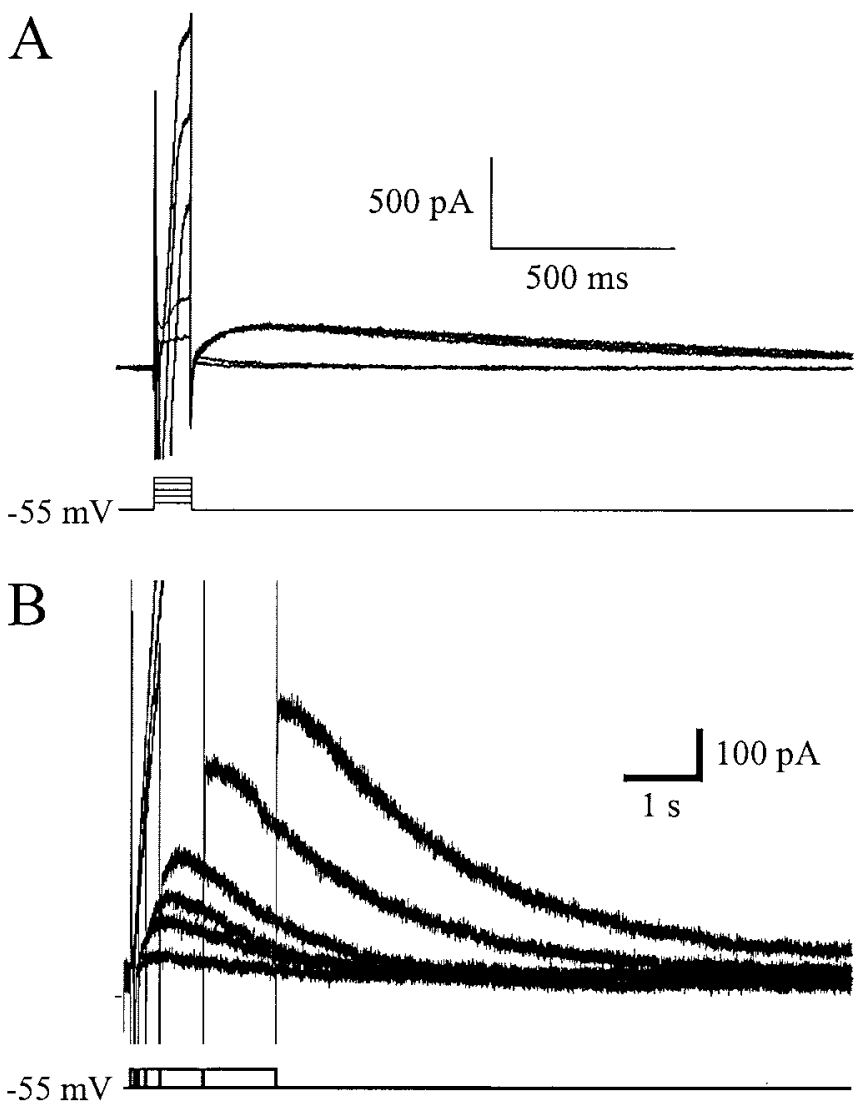

Figure 3. $\mathrm{Ca}^{2+}$ influx and $\mathrm{s} I_{\mathrm{AHP}} \cdot A$, An example of the $I_{\mathrm{AHP}}$ in response to depolarizing voltage steps from -50 to $-10 \mathrm{mV}$, in increments of 10 $\mathrm{mV}$. For leak subtraction, $2 \mathrm{mV}$ step potentials were used. Note that although increasing the amplitude of the voltage pulse increased the amplitude of the $\mathrm{s} I_{\mathrm{AHP}}$, no significant $\mathrm{s} I_{\mathrm{AHP}}$ was observed until an obvious $\mathrm{Ca}^{2+}$ transient was elicited by the step potentials. $B$, Increasing the pulse duration also increased the amplitude of the $s I_{\mathrm{AHP}}$. The $\mathrm{s} I_{\mathrm{AHP}}$ was activated with depolarizing steps from -50 to $-30 \mathrm{mV}$ with varying durations. Voltage steps with longer durations allowed for more $\mathrm{Ca}^{2+}$ influx, thereby increasing the $\mathrm{s} I_{\mathrm{AHP}}$.

1984; Pitler and Landfield, 1990; Moyer and Disterhoft, 1994; Campbell et al., 1996), partially attributable to an increase in the functional L-type $\mathrm{Ca}^{2+}$ channel density (Thibault and Landfield, 1996; Chen et al., 2000), in neurons from aging animals. Furthermore, the enhancements in the AHP and the plateau phase of the $\mathrm{Ca}^{2+}$ action potential in aging neurons are both reduced by nimodipine, an L-type $\mathrm{Ca}^{2+}$ channel blocker (Moyer and Disterhoft, 1994), raising a possibility that the enhanced $\mathrm{s} I_{\mathrm{AHP}}$ in aging neurons is secondary to an enhanced L-type $\mathrm{Ca}^{2+}$ influx. To investigate whether age-related enhancement of the $I_{\mathrm{AHP}}$ is secondary to an enhanced L-type $\mathrm{Ca}^{2+}$ influx, we examined the $\mathrm{s} I_{\mathrm{AHP}}$ before and after bath applications of nimodipine $(10 \mu \mathrm{M})$. Aging-related enhancement of the $\mathrm{s} I_{\mathrm{AHP}}(p<0.0005)$ was replicated and reported in Table 3. Bath application of nimodipine significantly reduced the integrated area of the $I_{\mathrm{AHP}}-\mathrm{S} I_{\mathrm{AHP}}$, as well as the amplitude of the $\mathrm{s} I_{\mathrm{AHP}}$, at $1 \mathrm{sec}$ after pulse offset ( $p$ $<0.0001$ ) (Fig. 5). Nimodipine reduced both the area of the $I_{\mathrm{AHP}}-\mathrm{S} I_{\mathrm{AHP}}$ and the amplitude of the $I_{\mathrm{AHP}}$ in young and aging neurons by $<25$ and $<30 \%$, respectively (Fig. $6 A$ ). Consistent with our previous study (Moyer and Disterhoft, 1994), nimodipine caused quantitatively greater reductions in the integrated area of the $I_{\mathrm{AHP}}-\mathrm{S} I_{\mathrm{AHP}}$ and the amplitude of the $\mathrm{s} I_{\mathrm{AHP}}$ in aging 

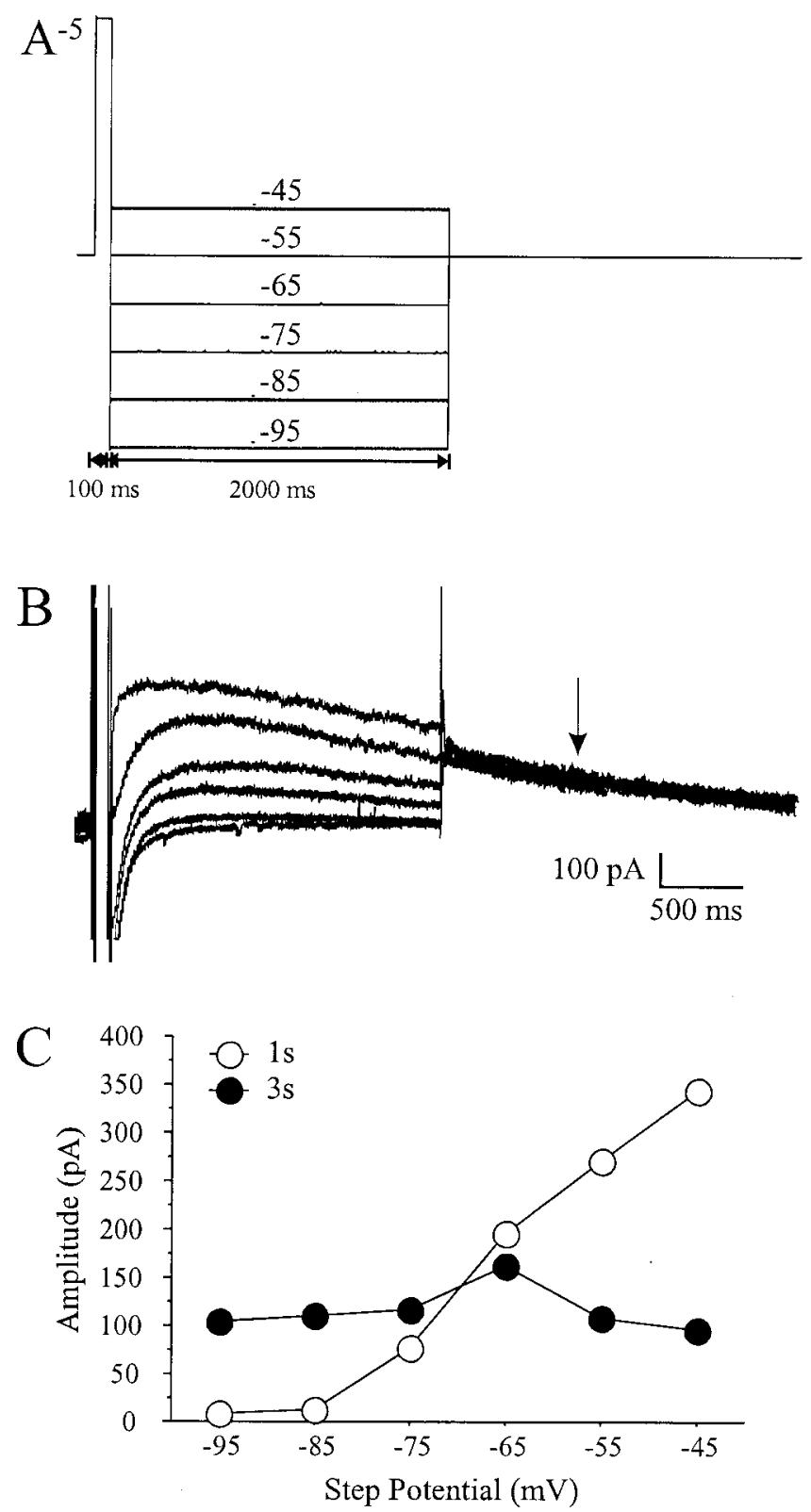

Figure 4. Voltage independence and reversal potential of the AHP tail current. $A$, The protocol for measuring the voltage dependence of the $\mathrm{s} I_{\mathrm{AHP}}$ tail current. The $\mathrm{s} I_{\mathrm{AHP}}$ tail current was evoked by a $100 \mathrm{msec}, 50$ $\mathrm{mV}$ pulse from a holding potential of $-55 \mathrm{mV}$. After the voltage pulse, membrane potential was stepped to various test potentials for $2 \mathrm{sec}$ before returning to the $-55 \mathrm{mV}$ holding potential. For leak subtraction, the neurons were stepped to the test potentials for $2 \mathrm{sec}$ without the $100 \mathrm{msec}$, $50 \mathrm{mV}$ prepulse to elicit the $\mathrm{s} I_{\mathrm{AHP}}$ tail current. $B$, Representative currents evoked from the voltage-dependence protocol. $C$, The reversal potential was obtained by linear extrapolation of the voltage versus $\mathrm{s} I_{\mathrm{AHP}}$ amplitude at $1 \mathrm{sec}$ to the voltage axis. The reversal potential of the $\mathrm{s} I_{\mathrm{AHP}}$ in this example was $-90 \mathrm{mV}$. Similar to previous reports, the $\mathrm{s} I_{\mathrm{AHP}}$ conductance did not show any voltage dependence at either age (young: $n=7$; aging: $n=11$ ). The test potentials did not alter the decay rate of the current, and amplitude of the $\mathrm{s} I_{\mathrm{AHP}}$ measured at $1 \mathrm{sec}$ after the various test potentials (labeled as $3 s$ and denoted with an arrow) remained the same.

neurons than in young neurons $(p<0.05)$ (Fig. $6 B)$. The residual area of the $I_{\mathrm{AHP}}-\mathrm{s} I_{\mathrm{AHP}}$ and the amplitude of the $\mathrm{s} I_{\mathrm{AHP}}$ were still significantly larger in aging neurons than in young neurons (amplitude for young $=117.3 \pm 17.65 \mathrm{pA}$; for old, $190.0 \pm 21.47 \mathrm{pA}$; $p=0.01$ ) (Fig. 6C). Hence, our data are consistent with observations of an enhanced L-type $\mathrm{Ca}^{2+}$ influx in aging neurons. However, this enhanced L-type $\mathrm{Ca}^{2+}$ influx cannot fully account for the aging-related enhancement in the $\mathrm{s} I_{\mathrm{AHP}}$.

\section{DISCUSSION}

In hippocampal pyramidal neurons, excitability is controlled by a pronounced AHP. Based on kinetics and pharmacological criteria, the AHP can be separated into fast, medium, and slow components (for review, see Storm, 1990; Sah, 1996). In neurons from trace eyeblink conditioned animals, both the peak amplitude of the AHP and its duration are decreased (Moyer et al., 1996, 2000; Thompson et al., 1996b). In contrast, both parameters are increased in neurons from naive aging animals (Landfield and Pitler, 1984; Moyer et al., 1992). After pharmacologically isolating the slow components of the AHP $\left(I_{\mathrm{AHP}}-\mathrm{S} I_{\mathrm{AHP}}\right)$, we found agerelated enhancements in the integrated area (mixed $I_{\mathrm{AHP}}{ }^{-\mathrm{S}} I$ AHP), the peak amplitude (mixed $I_{\mathrm{AHP}}-\mathrm{S} I_{\mathrm{AHP}}$ ), and the amplitudes at 1 and $2 \mathrm{sec}$ after pulse offset ( $\mathrm{S} I_{\mathrm{AHP}}$ alone) for the AHP tail current. We did not pharmacologically separate the $I_{\mathrm{AHP}}$ and the $I_{\mathrm{AHP}}$. However, in CA1 pyramidal neurons from rabbits and rats, the apamin-sensitive $I_{\mathrm{AHP}}$ accounts for only a small percentage $(\sim 20 \%)$ of the total AHP (Stocker et al., 1999; Oh et al., 2000). Furthermore, blocking $I_{\mathrm{AHP}}$ with saturating concentrations of apamin had only small effects on accommodation (Oh et al., 2000). Thus by inference, the reduced neuronal excitability observed in aging neurons can mostly be attributed to an enhanced $\mathrm{s} I_{\mathrm{AHP}}$. Consistent with this hypothesis, the amplitude measurements of the $I_{\mathrm{AHP}}$ correlated with the integrated area, as well as amplitude measurements, of the AHP, further supporting the possibility that an enhanced $\mathrm{s} I_{\mathrm{AHP}}$ underlies an enhanced AHP in aging.

Many factors can lead to an enhanced $\mathrm{s} I_{\mathrm{AHP}}$ in aging. Increased leak conductance is not likely to be one of them, because neurons of both age groups shared similar membrane resistances. Although aging neurons rested at more hyperpolarizing potentials, the reversal potentials for the $\mathrm{s} I_{\mathrm{AHP}}$ were similar in both young and aging neurons. Furthermore, when the cells were grouped by resting membrane potentials, aging neurons still had significantly larger $\mathrm{s} I_{\mathrm{AHP}}$ than young neurons, suggesting that changes in the driving force for $\mathrm{K}^{+}$ions do not contribute to an enhanced $\mathrm{s} I_{\mathrm{AHP}}$ in aging. The slow AHP is also affected by conductances that control spike broadening, and hence the amount of $\mathrm{Ca}^{2+}$ influx, such as the A-type voltage-dependent $\mathrm{K}^{+}$current (Giese et al., 1998). The enhanced $\mathrm{s} I_{\mathrm{AHP}}$ that we observed in aging neurons is not caused by alterations in these conductances, because all voltage-clamp recordings were performed in the presence of 4-AP and TEA.

The $\mathrm{s}_{\mathrm{AHP}}$ is a $\mathrm{Ca}^{2+}$-dependent $\mathrm{K}^{+}$current that is modulated by many neurotransmitters. Therefore, its amplitude also depends on (1) the amount of $\mathrm{Ca}^{2+}$ available to cause channel activation, (2) the degree of modulation, and (3) channel conductance and functional density of the $\mathrm{s} I_{\mathrm{AHP}}$ channels. Many studies have shown altered $\mathrm{Ca}^{2+}$ homeostasis in aging neurons. Changes in voltage-gated $\mathrm{Ca}^{2+}$ influx (Landfield and Pitler, 1984; Moyer et al., 1992; Thibault and Landfield, 1996) and intracellular $\mathrm{Ca}^{2+}$ release (Martini et al., 1994), as well as an elevation in the free cytosolic $\mathrm{Ca}^{2+}$ concentration, most likely resulting from a combination of disrupted $\mathrm{Ca}^{2+}$ handling, buffering, sequestration, and efflux mechanisms (Khachaturian, 1989; Disterhoft et al., 1993, 1994; Thibault et al., 1998; Verkhratsky and Toescu, 1998), have all been implicated in aging. Exactly how these changes 
Table 2. Correlation between current-clamp and voltage-clamp measurements

\begin{tabular}{|c|c|c|c|c|}
\hline \multirow[b]{2}{*}{ AHP tail current } & \multicolumn{2}{|c|}{ Post-burst AHP (mV) } & \multicolumn{2}{|c|}{ Post-burst AHP area (mV msec) } \\
\hline & $r$ & $p$ values & $r$ & $p$ values \\
\hline Peak amplitude (pA) & -0.683 & 0.0002 & -0.463 & 0.0248 \\
\hline Latency to peak amplitude (msec) & 0.327 & 0.1292 & 0.200 & 0.3635 \\
\hline 200 msec amplitude (pA) & -0.654 & 0.0005 & -0.564 & 0.0043 \\
\hline $1 \mathrm{sec}$ amplitude (pA) & -0.631 & 0.0009 & -0.582 & 0.0029 \\
\hline $2 \mathrm{sec}$ amplitude (pA) & -0.592 & 0.0023 & -0.514 & 0.0110 \\
\hline Area $(\mathrm{pC})$ & -0.618 & 0.0012 & -0.542 & 0.0066 \\
\hline Half decay 200 (msec) & -0.141 & 0.5241 & -0.177 & 0.4245 \\
\hline Half decay 800 (msec) & -0.291 & 0.1802 & -0.167 & 0.4500 \\
\hline Decay tau (msec) & 0.252 & 0.2494 & 0.219 & 0.3193 \\
\hline
\end{tabular}

Amplitude and area of the AHP were correlated to amplitudes and area of the slow outward tail current. Correlations, $r$, were performed using Fisher's $r$ to $z$. Significant effects are highlighted in bold.

Table 3. Effect of nimodipine on young and aging neurons

\begin{tabular}{|c|c|c|c|c|c|c|c|c|c|}
\hline \multirow[b]{2}{*}{ AHP tail measures } & \multicolumn{3}{|l|}{ Young } & \multicolumn{3}{|l|}{ Aging } & \multicolumn{3}{|c|}{$p$ values } \\
\hline & Mean & SEM & $n$ & Mean & SEM & $n$ & $\mathrm{~T}$ & $\mathrm{~F}$ & $\mathrm{U}$ \\
\hline \multicolumn{10}{|l|}{$\mathrm{s} I_{\mathrm{AHP}}-\mathrm{aCSF}$} \\
\hline Peak amplitude (pA) & 214.8 & 21.0 & 30 & 353.6 & 27.5 & 35 & 0.0002 & 0.0567 & 0.0005 \\
\hline Latency to peak amplitude (msec) & 403.4 & 33.4 & 30 & 445.8 & 33.9 & 35 & 0.3796 & & \\
\hline 200 msec amplitude $(\mathrm{pA})$ & 189.5 & 23.6 & 30 & 317.3 & 43.2 & 35 & 0.0008 & 0.0704 & \\
\hline $1 \mathrm{sec}$ amplitude $(\mathrm{pA})$ & 143.2 & 15.8 & 30 & 262.4 & 23.5 & 35 & & 0.0096 & 0.0002 \\
\hline 2 sec amplitude (pA) & 74.0 & 11.1 & 30 & 128.5 & 18.1 & 35 & & 0.0021 & 0.0095 \\
\hline Area $(\mathrm{pC})$ & 253.7 & 36.9 & 30 & 646.8 & 67.4 & 35 & & 0.0012 & 0.0005 \\
\hline \multicolumn{10}{|l|}{ With nimodipine } \\
\hline Peak amplitude (pA) & 164.5 & 22.9 & 25 & 266.0 & 26.7 & 31 & 0.007 & 0.1859 & \\
\hline Latency to peak amplitude (msec) & 475.8 & 37.1 & 25 & 460.9 & 38.8 & 31 & 0.785 & & \\
\hline 200 msec amplitude $(\mathrm{pA})$ & 127.6 & 24.0 & 25 & 226.4 & 26.3 & 31 & 0.009 & 0.3072 & \\
\hline $1 \mathrm{sec}$ amplitude $(\mathrm{pA})$ & 117.3 & 17.7 & 25 & 190.0 & 21.5 & 31 & 0.014 & 0.1231 & \\
\hline 2 sec amplitude (pA) & 59.4 & 9.4 & 25 & 107.8 & 15.5 & 31 & & 0.0027 & 0.040 \\
\hline Area $(\mathrm{pC})$ & 286.5 & 46.0 & 25 & 465.9 & 57.4 & 31 & 0.022 & 0.0953 & \\
\hline
\end{tabular}

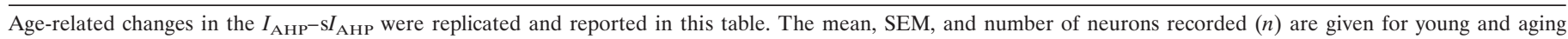

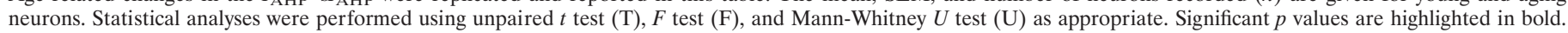

affect the $\mathrm{s} I_{\mathrm{AHP}}$ is unclear. For example, it has been hypothesized that the age-related enhancement of the AHP is secondary to an enhanced $\mathrm{Ca}^{2+}$ influx (Pitler and Landfield, 1990), particularly that through the L-type $\mathrm{Ca}^{2+}$ channels (Campbell et al., 1996; Thibault and Landfield, 1996; Chen et al., 2000). In this study, we addressed this possibility by examining the effect of nimodipine on the $\mathrm{S} I_{\mathrm{AHP}}$ in the context of aging. Saturating concentrations of nimodipine caused quantitatively greater reductions in the $\mathrm{s} I_{\mathrm{AHP}}$ in aging neurons than in young neurons, suggesting that the contribution of the L-type $\mathrm{Ca}^{2+}$ influx to activate the $\mathrm{s} I_{\mathrm{AHP}}$ is enhanced in aging. However, after blocking the L-type $\mathrm{Ca}^{2+}$ influx, the residual $\mathrm{s} I_{\mathrm{AHP}}$ from aging neurons remained significantly larger than that of the young neurons, indicating that the enhanced L-type $\mathrm{Ca}^{2+}$ influx alone cannot account for the agingrelated enhancement of the $\mathrm{s} I_{\mathrm{AHP}}$.

Although nimodipine is a highly lipophilic compound, and its diff usion through slices can be problematic, it is not likely that the enhanced $\mathrm{s} I_{\mathrm{AHP}}$ in aging neurons observed in the presence of nimodipine is caused by differences in the amount of unblocked L-type $\mathrm{Ca}^{2+}$ currents. In this study, saturating concentrations of nimodipine were applied for at least $10 \mathrm{~min}$ before recording. In addition, recordings were typically made from CA1 pyramidal neurons at no more than $100 \mu \mathrm{m}$ below the surface of the slice.
Previously our laboratory has shown that the L-type $\mathrm{Ca}^{2+}$ current in aging neurons can be blocked with lower concentrations of nimodipine than that of the young neuron (Moyer et al., 1992). In the unlikely event of a diffusion problem, these data suggest a greater likelihood for residual L-type $\mathrm{Ca}^{2+}$ current to exist in young neurons than in aging neurons. In such a case, the agingrelated enhancement of the $\mathrm{s} I_{\mathrm{AHP}}$ that is independent of the L-type $\mathrm{Ca}^{2+}$ influx reported here would be an underestimation. $\mathrm{Ca}^{2+}$ that activates the $\mathrm{s} I_{\mathrm{AHP}}$ also comes from intracellular $\mathrm{Ca}^{2+}$ store release through a process known as $\mathrm{Ca}^{2+}$-induced $\mathrm{Ca}^{2+}$ release (CICR) (Sah and McLachlan, 1991; Torres et al., 1995, 1996; Tanabe et al., 1998; Shah and Haylett, 2000). Whether altered CICR contributes to an enhanced $\mathrm{s} I_{\mathrm{AHP}}$ in aging remains speculative.

The amplitude of the $\mathrm{s} I_{\mathrm{AHP}}$ also depends on the degree of neuromodulation it receives. The $\mathrm{s} I_{\mathrm{AHP}}$ is reduced by metabotropic glutamate agonists (Liu et al., 1993), acetylcholine (Madison et al., 1987), serotonin (Colino and Halliwell, 1987), histamine (Haas and Greene, 1986), dopamine (Malenka and Nicoll, 1986), noradrenaline (Haas and Konnerth, 1983; Madison and Nicoll, 1986), corticotropin releasing factor (Fox and Gruol, 1993), vasoactive intestinal peptide (Haas and Gahwiler, 1992), and calcitonin gene-related peptide (Nohmi et al., 1986). Many of 
YOUNG

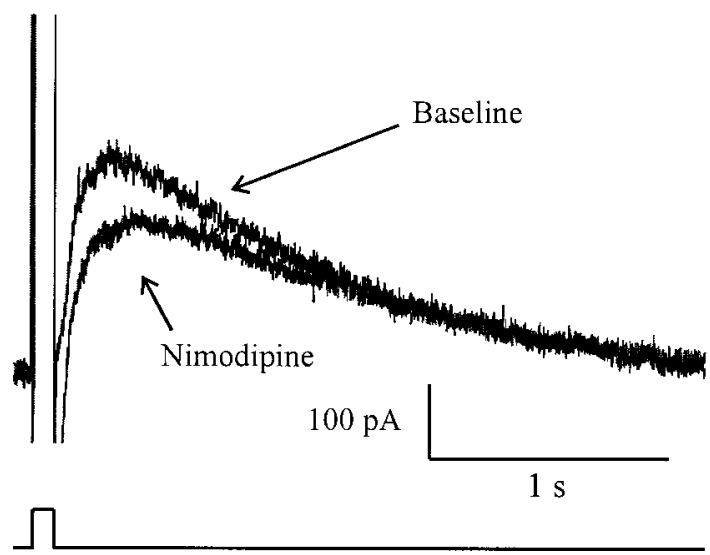

AGING

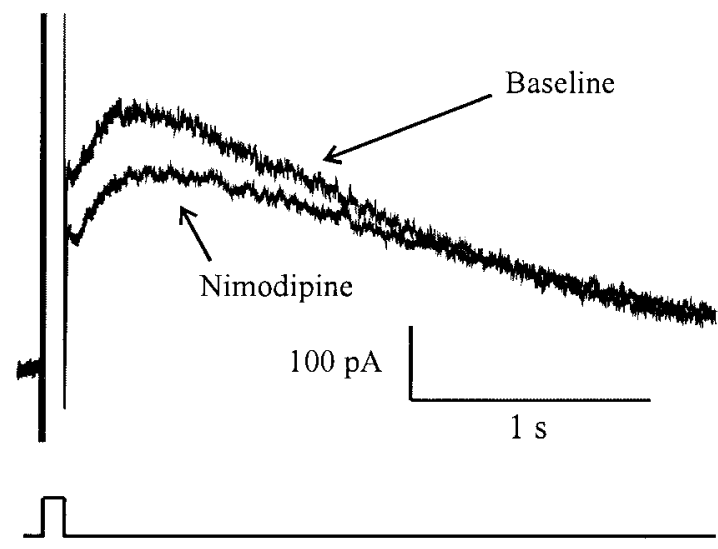

Figure 5. The effect of L-type $\mathrm{Ca}^{2+}$ influx on the $\mathrm{s} I_{\mathrm{AHP}}$. Shown are representative current traces from young and aging neurons before and after bath applications of nimodipine.

Figure 6. A, Bath application of nimodipine caused a comparable percentage $(25-30 \%)$ of reduction in the $\mathrm{s} I_{\mathrm{AHP}}$ of young and aging neurons. $B$, The amount of reductions in the $\mathrm{s} I_{\mathrm{AHP}}(1 \mathrm{sec}$ amplitude) and the AHP current (integrated area) was significantly larger in aging than in young neurons (unpaired $t$ test; $* p<0.05$ and $* * p<0.001$, respectively; $n=31$ for aging; $n=25$ for young). $C$, After eliminating the contribution of the L-type $\mathrm{Ca}^{2+}$ influx on the $\mathrm{s} I_{\mathrm{AHP}}$ with bath-applied nimodipine, the residual $\mathrm{s} I_{\mathrm{AHP}}$ and AHP current were still significantly larger in the aging neurons than in the young neurons (unpaired $t$ test; $\left.{ }^{*} p<0.05\right)$.
A

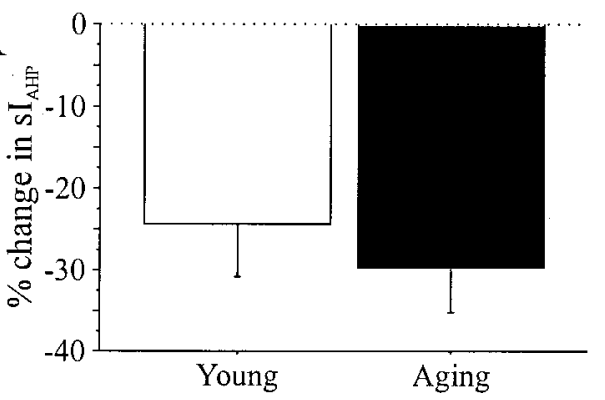

B

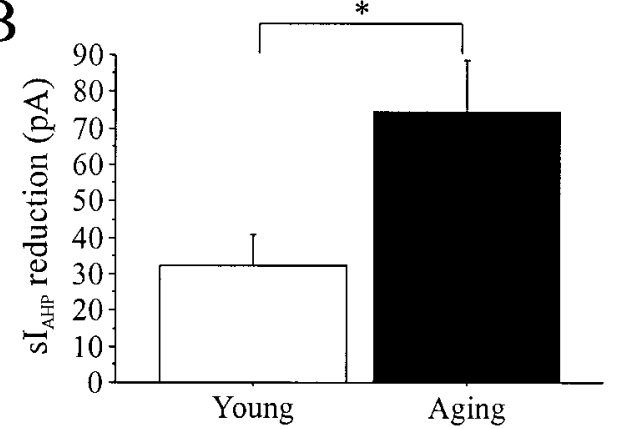

$\mathrm{C}$

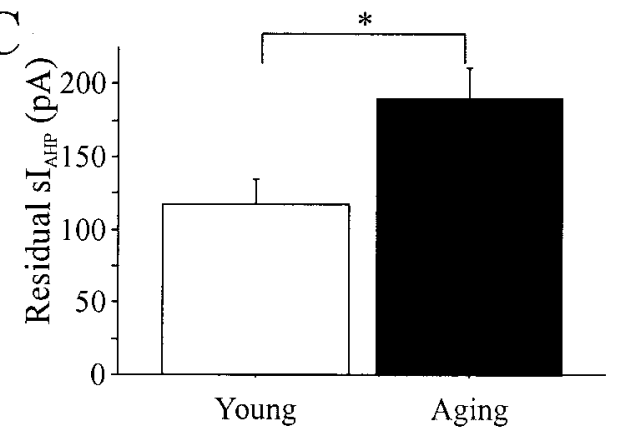

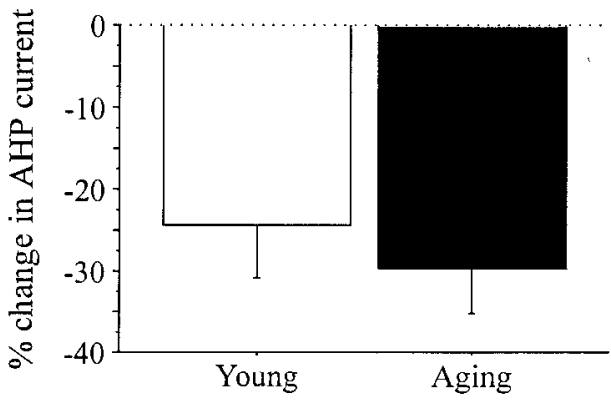
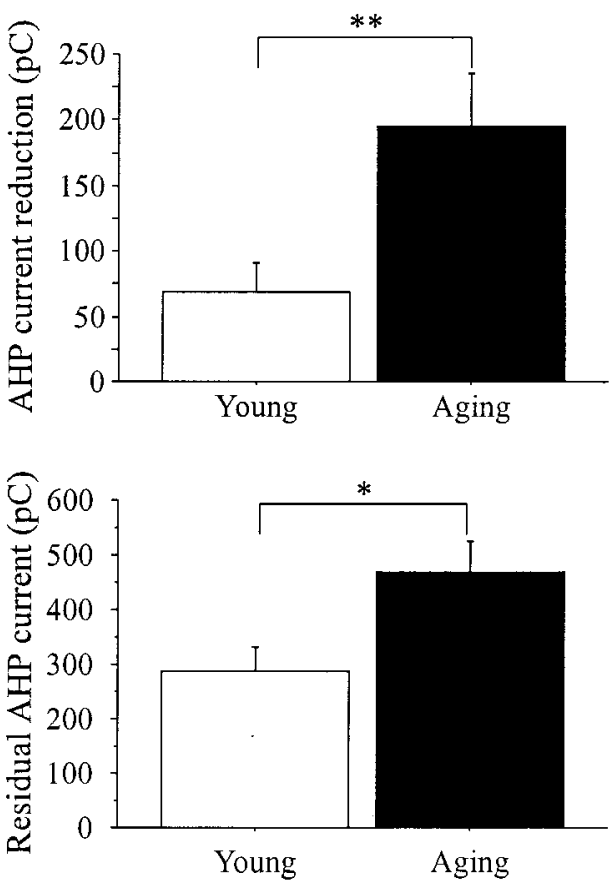

these molecules were shown to suppress the $\mathrm{S} I_{\mathrm{AHP}}$ through protein kinase activities (Gerber et al., 1992; Müller et al., 1992; Pedarzani and Storm 1993, 1995, 1996; Torres et al., 1995; AbdulGhani et al., 1996; Haug and Storm, 2000). Changes in many of these neurotransmitter systems (Luine et al., 1990; Fischer et al., 1992; Smith and Booze, 1995; Richter-Levin and Segal, 1996;
Miguez et al., 1999; Stemmelin et al., 2000; Segovia et al., 2001), as well as their effector kinases (Colombo et al., 1997; Pascale et al., 1998), have been implicated in aging. Conceivably, altered neurotransmission in aging, coupled with altered kinase functions, can shift the balance between kinase and phosphatase activities that normally maintain the $\mathrm{s}_{\mathrm{AHP}}$ (Pedarzani et al., 
1998) and alter this current. The enhanced $\mathrm{s} I_{\mathrm{AHP}}$ in aging neurons that we report in this study is a postsynaptic phenomenon and does not reflect changes in basal neurotransmission, because our slices were perfused in aCSF containing TTX as well as glutamatergic and GABAergic antagonists.

Age-related changes in the functional $\mathrm{s} I_{\mathrm{AHP}}$ channel density as well as the channel properties can also affect the $\mathrm{s} I_{\mathrm{AHP}}$. Whether these mechanisms contribute to the enhanced $\mathrm{s} I_{\mathrm{AHP}}$ in aging remains to be addressed.

Molecules that affect the $\mathrm{s} I_{\mathrm{AHP}}$ have also been implicated in other forms of plasticity. For example, kinases known to modulate the $\mathrm{s} I_{\mathrm{AHP}}(\mathrm{PKC}, \mathrm{PKA}$, and calcium-calmodulin kinase II) are also important for the induction of long-term potentiation (LTP), a model for cellular mechanisms of learning and memory (for review, see Soderling and Derkach, 2000). Currently, the $\mathrm{s} I_{\mathrm{AHP}}$ channels are thought to be located on apical or basal dendrites close to the soma (Sah and Bekkers, 1996; Bekkers, 2000), although a recent study by Lancaster et al. (2001) questions the basal dendritic location, suggesting a role for the $\mathrm{S}_{\mathrm{AHP}}$ in controlling dendritic excitability and synaptic integration (LoTurco et al., 1988; Andreasen and Lambert, 1995). Consistent with this hypothesis, activation of the $\mathrm{s} I_{\mathrm{AHP}}$ dampens temporal summation of the EPSPs as well as speeds up their decay rate (Lancaster et al., 2001). Pharmacological manipulations that facilitated LTP have also been shown to reduce the AHP (Cohen et al., 1999), suggesting that the AHP and its underlying currents can serve as an adjustable gain control, variably hyperpolarizing and shunting synaptic potentials arising in the distal dendrites and controlling the induction of further plasticity (Sah and Bekkers, 1996). Accordingly, the enhanced $s I_{\mathrm{AHP}}$ in aging can hamper the formation of further plastic alterations important for learning and memory (Dunwiddie et al., 1992; Sah and Bekkers, 1996; Giese et al., 2001).

The correlation between the AHP (and thus, accommodation) and learning have led us to hypothesize that the enhancement in the AHP is involved in aging-related memory deficits. Here we report that this AHP enhancement in aging is attributable to an enhanced $\mathrm{s} I_{\mathrm{AHP}}$. In addition, the variance of the $\mathrm{s} I_{\mathrm{AHP}}$ amplitude increases with age, strikingly similar to the age-related heterogeneity of learning observed in rabbits of the same age (Thompson et al., 1996a). The data presented in this study have allowed us to refine our initial hypothesis: enhancement of the $\mathrm{s} I_{\mathrm{AHP}}$ is involved in age-related learning deficits. In support of our hypothesis, we have shown that nimodipine facilitates acquisition of the trace eyeblink conditioned response and reduces the AHP in animals (Deyo et al., 1989; Moyer et al., 1992; Kowalska and Disterhoft, 1994). In this study, we have further shown that nimodipine reduces the $\mathrm{s} I_{\mathrm{AHP}}$ in young and aging animals. Similarly, chronic treatment with metrifonate, a cholinesterase inhibitor, or CI1017, an M1 muscarinic agonist, both reduce the $I_{\mathrm{AHP}}$ and the slow AHP and facilitate trace eyeblink conditioning in aging rabbits (Kronforst-Collins et al., 1997; Oh et al., 1999; Weiss et al., 2000; Power et al., 2001). The cholinergic reduction of the $\mathrm{s}_{\mathrm{AHP}}$ is independent of $\mathrm{Ca}^{2+}$ entry (Muller and Connor, 1991), suggesting that the cognitive benefits of procholinergic treatments are caused by a reduction of the $\mathrm{s} I_{\mathrm{AHP}}$ itself. We are unaware of experiments designed to disrupt learning by enhancing the $\mathrm{s}_{\mathrm{AHP}}$. However, treatment with the central cholinergic blocker scopolamine, which should eliminate cholinergic reduction of the $\mathrm{s} I_{\mathrm{AHP}}$, disrupts trace eyeblink conditioning in young rabbits (Kaneko and Thompson, 1997). The results of the present study provide additional support for an involvement of the en- hanced $\mathrm{s} I_{\mathrm{AHP}}$ in age-related learning deficits, and further suggest that key modulators of this current are good candidates for future therapeutic interventions in age-related cognitive impairments.

\section{REFERENCES}

Abdul-Ghani MA, Valiante TA, Carlen PL, Pennefather PS (1996) Tyrosine kinase inhibitors enhance a $\mathrm{Ca}(2+)$-activated $\mathrm{K}+$ current (IAHP) and reduce IAHP suppression by a metabotropic glutamate receptor agonist in rat dentate granule neurones. J Physiol (Lond) 496:139-144.

Andreasen M, Lambert JD (1995) The excitability of CA1 pyramidal cell dendrites is modulated by a local $\mathrm{Ca}(2+)$-dependent $\mathrm{K}(+)$ conductance. Brain Res 698:193-203.

Bekkers JM (2000) Distribution of slow AHP channels on hippocampal CA1 pyramidal neurons. J Neurophysiol 83:1756-1759.

Blanton MG, LoTurco JJ, Kriegstein AR (1989) Whole cell recording from neurons in slices of reptilian and mammalian cerebral cortex. J Neurosci Methods 30:203-210.

Campbell LW, Hao SY, Thibault O, Blalock EM, Landfield PW (1996) Aging changes in voltage-gated calcium currents in hippocampal CA1 neurons. J Neurosci 16:6286-6295.

Chen KC, Blalock EM, Thibault O, Kaminker P, Landfield PW (2000) Expression of alpha 1D subunit mRNA is correlated with L-type Ca2+ channel activity in single neurons of hippocampal "zipper" slices. Proc Natl Acad Sci USA 97:4357-4362.

Cohen AS, Coussens CM, Raymond CR, Abraham WC (1999) Longlasting increase in cellular excitability associated with the priming of LTP induction in rat hippocampus. J Neurophysiol 82:3139-3148.

Cohen NJ, Eichenbaum H (1993) Memory, amnesia, and the hippocampal system. Cambridge, MA: MIT.

Colino A, Halliwell JV (1987) Differential modulation of three separate K-conductances in hippocampal CA1 neurons by serotonin. Nature 328:73-77.

Colombo PJ, Wetsel WC, Gallagher M (1997) Spatial memory is related to hippocampal subcellular concentrations of calcium-dependent protein kinase C isoforms in young and aged rats. Proc Natl Acad Sci USA 94:14195-14199.

Constanti A, Sim JA (1987) Calcium-dependent potassium conductance in guinea-pig olfactory cortex neurones in vitro. J Physiol (Lond) 387:173-194.

Coulter DA, LoTurco J, Kubota M, Disterhoft JF, Moore JW, Alkon DL (1989) Classical conditioning reduces the amplitude and duration of the calcium-dependent afterhyperpolarization in rabbit hippocampal pyramidal cells. J Neurophysiol 61:971-981.

Deyo RA, Straube KT, Disterhoft JF (1989) Nimodipine facilitates associative learning in aging rabbits. Science 243:809-811.

Disterhoft JF, Coulter DA, Alkon DL (1986) Conditioning-specific membrane changes of rabbit hippocampal neurons measured in vitro, Proc Natl Acad Sci USA 83:2733-2737.

Disterhoft JF, Moyer Jr JR, Thompson LT (1993) The calcium rationale in Alzheimer's disease. New York: Raven.

Disterhoft JF, Gispen WH, Traber J, Khatchaturian AS (1994) Calcium hypothesis of aging and dementia. Ann NY Acad Sci 747.

Disterhoft JF, Thompson LT, Moyer Jr JR, Mogul DJ (1996) Calciumdependent afterhyperpolarization and learning in young and aging hippocampus. Life Sci 59:413-420.

Dodt HU, Zieglansberger W (1990) Visualizing unstained neurons in living brain slices by infrared DIC-videomicroscopy. Brain Res 537:333-336.

Dunwiddie TV, Taylor M, Heginbotham LR, Proctor WR (1992) Longterm increases in excitability in the CA1 region of rat hippocampus induced by $\beta$-adrenergic stimulation: possible mediation by cAMP. J Neurosci 12:506-517.

Fischer W, Chen KS, Gage FH, Bjorklund A (1992) Progressive decline in spatial learning and integrity of forebrain cholinergic neurons in rats during aging. Neurobiol Aging 13:9-23.

Fox EA, Gruol DL (1993) Corticotropin-releasing factor suppresses the afterhyperpolarization in cerebellar Purkinje neurons. Neurosci Lett 149:103-107.

Gerber U, Sim JA, Gähwiler BH (1992) Reduction of potassium conductances mediated by metabotropic glutamate receptors in rat CA3 pyramidal cells does not require protein kinase $\mathrm{C}$ or protein kinase $\mathrm{A}$. Eur J Neurosci 4:792-797.

Giese KP, Storm JF, Reuter D, Fedorov NB, Shao LR, Leicher T, Pongs O, Silva AJ (1998) Reduced K+ channel inactivation, spike broadening, and after-hyperpolarization in Kvbeta1.1-deficient mice with impaired learning. Learn Mem 5:257-273.

Giese KP, Peters M, Vernon J (2001) Modulation of excitability as a learning and memory mechanism: a molecular genetic perspective. Physiol Behav 73:803-810.

Haas H, Greene RW (1984) Adenosine enhances afterhyperpolarization and accommodation in hippocampal pyramidal cells. Pflügers Arch 402:244-247. 
Haas H, Greene RW (1986) Effects of histamine on hippocampal pyramidal cells of rats in vitro. Exp Brain Res 62:123-130.

Haas HL, Gahwiler BH (1992) Vasoactive intestinal polypeptide modulates neuronal excitability in hippocampal slices of the rat. Neuroscience 47:273-277.

Haas HL, Konnerth A (1983) Histamine and noradrenaline decrease calcium-activated potassium conductance in hippocampal pyramidal cells. Nature 302:432-434.

Haug T, Storm JF (2000) Protein kinase A mediates the modulation of the slow $\mathrm{Ca}(2+)$-dependent $\mathrm{K}(+)$ current, I(sAHP), by the neuropeptides CRF, VIP, and CGRP in hippocampal pyramidal neurons. J Neurophysiol 83:2071-2079.

Kaneko T, Thompson RF (1997) Disruption of trace conditioning of the nictitating membrane response in rabbits by central cholinergic blockade. Psychopharmacology 131:161-166.

Khachaturian ZS (1989) The role of calcium regulation in brain aging: reexamination of a hypothesis. Aging 1:17-34.

Kim J, Clark R, Thompson RF (1995) Hippocampectomy impairs the memory of recently, but not remotely, acquired trace eyeblink conditioned responses. Behav Neurosci 109:195-203.

Knuttinen MG, Gamelli AE, Weiss C, Power JM, Disterhoft JF (2001a) Age-related effects on eyeblink conditioning in the F344 x BN F1 hybrid rat. Neurobiol Aging 22:1-8.

Knuttinen MG, Power JM, Preston PR, Disterhoft JF (2001b) Awareness in classical differential eyeblink conditioning in young and aging humans. Behav Neurosci 115:747-757.

Kowalska M, Disterhoft JF (1994) Relation of nimodipine dose and serum concentration to learning enhancement in aging rabbits. Exp Neurol 127:159-166.

Kronforst-Collins MA, Moriearty PL, Schmidt B, Disterhoft JF (1997) Metrifonate improves associative learning and retention in aging rabbits. Behav Neurosci 111:1031-1040.

Lancaster B, Adams P (1986) $\mathrm{Ca}^{2+}$-dependent current generating the AHP of hippocampal neurons. J Neurophysiol 55:1268-1282.

Lancaster B, Hu H, Ramakers GM, Storm JF (2001) Interaction between synaptic excitation and slow afterhyperpolarization current in hippocampal pyramidal cells. J Physiol (Lond) 536:809-823.

Landfield PW, Pitler TA (1984) Prolonged Ca2+-dependent afterhyperpolarizations in hippocampal neurons of aged rats. Science 226: 1089-1092.

Liu YB, Disterhoft JF, Slater NT (1993) Activation of metabotropic glutamate receptors induces long-term depression of GABAergic inhibition in hippocampus. J Neurophysiol 69:1000-1004.

LoTurco JL, Coulter DA, Alkon DL (1988) Enhancement of synaptic potentials in rabbit CA1 pyramidal neurons following classical conditioning. Proc Natl Acad Sci USA 85:1672-1676.

Luine V, Bowling D, Hearns M (1990) Spatial memory deficits in aged rats: contributions of monoaminergic systems. Brain Res 537:271-278.

Maccaferri G, Mangoni M, Lazzari A, DiFrancesco D (1993) Properties of the hyperpolarization-activated current in rat hippocampal CA1 pyramidal cells. J Neurophysiol 69:2129-2136.

Madison D, Nicoll RA (1986) Actions of noradrenaline recorded intracellularly in rat hippocampal CA1 pyramidal neurons, in vitro. J Physiol (Lond) 372:221-244.

Madison DV, Lancaster B, Nicoll RA (1987) Voltage-clamp analysis of cholinergic action in the hippocampus. J Neurosci 7:733-741.

Malenka RC, Nicoll RA (1986) Dopamine decreases the calciumactivated afterhyperpolarization in hippocampal CA1 pyramidal cells. Brain Res 379:210-215.

Martini A, Battaini F, Govoni S, Volpe P (1994) Inositol 1, 4, 5-trisphosphate receptor and ryanodine receptor in the aging brain of Wistar rats. Neurobiol Aging 15:203-206.

Miguez JM, Aldegunde M, Paz-Valinas L, Recio J, Sanchez-Barcelo E (1999) Selective changes in the contents of noradrenaline, dopamine and serotonin in rat brain areas during aging. J Neural Trans 106: 1089-1098.

Moyer Jr JR, Disterhoft JF (1994) Nimodipine decreases calcium action potentials in rabbit hippocampal CA1 neurons in an age- and concentration-dependent manner. Hippocampus 4:1-18.

Moyer Jr JR, Thompson LT, Black JP, Disterhoft JF (1992) Nimodipine increases excitability of rabbit CA1 pyramidal neurons in an age- and concentration-dependent manner. J Neurophysiol 68:2100-2109.

Moyer Jr JR, Thompson LT, Disterhoft JF (1996) Trace eyeblink conditioning increases CA1 excitability in a transient and learning-specific manner. J Neurosci 16:5536-5546.

Moyer Jr JR, Power JM, Thompson LT, Disterhoft JF (2000) Increased excitability of aged rabbit CA1 neurons after trace eyeblink conditioning. J Neurosci 20:5476-5482.

Müller W, Connor JA (1991) Cholinergic input uncouples $\mathrm{Ca}^{2+}$ changes from $\mathrm{K}^{+}$conductance activation and amplifies intradendritic $\mathrm{Ca}^{2+}$ changes in hippocampal neurons. Neuron 6:901-905.

Müller W, Petrozzino JJ, Griffith LC, Danho W, Connor JA (1992) Specific involvement of $\mathrm{Ca}(2+)$-calmodulin kinase II in cholinergic modulation of neuronal responsiveness. J Neurophysiol 68:2264-2269.
Neher E (1992) Correction for liquid junction potentials in patch clamp experiments. Methods Enzymol 207:123-131.

Nohmi M, Shinnick-Gallagher P, Gean PW, Gallagher JP, Cooper CW (1986) Calcitonin and calcitonin gene-related peptide enhance calcium-dependent potentials. Brain Res 367:346-350.

Oh MM, Power JM, Thompson LT, Moriarty P, Disterhoft JF (1999) Metrifonate increases neuronal excitability in CA1 pyramidal neurons from both young and aging rabbit hippocampus. J Neurosci 19:1814-1823

Oh MM, Power JM, Thompson LT, Disterhoft JF (2000) Apamin increases the excitability of CA1 hippocampal pyramidal neurons. Neurosci Res Commun 27:135-142.

Oh MM, Gamelli AE, Wu WW, Sametsky E, Disterhoft JF (2001) Morris watermaze learning enhances neuronal excitability of CA1 hippocampal pyramidal neurons in rats. Soc Neurosci Abstr 27:921.1.

Pascale A, Nogues X, Marighetto A, Micheau J, Battaini F, Govoni S, Jaffard R (1998) Cytosolic hippocampal PKC and aging: correlation with discrimination performance. NeuroReport 9:725-729.

Pedarzani P, Storm JF (1993) PKA mediates the effects of monoamine transmitters on the $\mathrm{K}+$ current underlying the slow spike frequency adaptation in hippocampal neurons. Neuron 11:1023-1035.

Pedarzani P, Storm JF (1995) Dopamine modulates the slow $\mathrm{Ca}(2+)$ activated $\mathrm{K}+$ current IAHP via cyclic AMP-dependent protein kinase in hippocampal neurons. J Neurophysiol 74:2749-2753.

Pedarzani P, Storm JF (1996) Evidence that Ca/calmodulin-dependent protein kinase mediates the modulation of the $\mathrm{Ca} 2+$-dependent $\mathrm{K}+$ current, IAHP, by acetylcholine, but not by glutamate, in hippocampa neurons. Pflügers Arch 431:723-728.

Pedarzani P, Krause M, Haug T, Storm JF, Stuhmer W (1998) Modulation of the $\mathrm{Ca} 2+$-activated $\mathrm{K}+$ current sIAHP by a phosphatasekinase balance under basal conditions in rat CA1 pyramidal neurons. J Neurophysiol 79:3252-3256.

Pitler TA, Landfield PW (1990) Aging-related prolongation of $\mathrm{Ca}^{2+}$ spike duration in rat hippocampal slice. Brain Res 508:1-6.

Power JM, Oh MM, Disterhoft JF (2001) Metrifonate decreases sI(AHP) in CA1 pyramidal neurons in vitro. J Neurophysiol 85:319-322.

Richter-Levin G, Segal M (1996) Serotonin, aging and cognitive functions of the hippocampus. Rev Neurosci 7:103-113.

Saar D, Grossman Y, Barkai E (1998) Reduced afterhyperpolarization in rat piriform cortex pyramidal neurons is associated with increased learning capability during conditioning. Eur J Neurosci 10:1518-1523.

Sah P (1996) Ca(2+)-activated K+ currents in neurones: types, physiological roles and modulation. Trends Neurosci 19:150-154.

Sah P, Bekkers JM (1996) Apical dendritic location of slow afterhyperpolarization current in hippocampal pyramidal neurons: implications for the integration of long-term potentiation. J Neurosci 16:4537-454.

Sah P, McLachlan EM (1991) Ca(2+)-activated K+ currents underlying the afterhyperpolarization in guinea pig vagal neurons: a role for $\mathrm{Ca}(2+)$-activated $\mathrm{Ca} 2+$ release. Neuron 7:257-264.

Sametsky EA, Wu WW, Oh MM, Moskal JR, Disterhoft JF (2001) Dorso-ventral gradient of excitability in hippocampal pyramidal neurons. Soc Neurosci Abstr 27:382.7.

Segovia G, Porras A, Del Arco A, Mora F (2001) Glutamatergic neurotransmission in aging: a critical perspective. Mech Ageing Dev 122:1-29.

Shah M, Haylett DG $(2000) \mathrm{Ca}(2+)$ channels involved in the generation of the slow afterhyperpolarization in cultured rat hippocampal pyramidal neurons. J Neurophysiol 83:2554-2561.

Soderling TR, Derkach VA (2000) Postsynaptic protein phosphorylation and LTP. Trends Neurosci 23:75-80.

Smith ML, Booze RM (1995) Cholinergic and GABAergic neurons in the nucleus basalis region of young and aged rats. Neuroscience 67:679-688.

Stemmelin J, Lazarus C, Cassel S, Kelche C, Cassel JC (2000) Immunohistochemical and neurochemical correlates of learning deficits in aged rats. Neuroscience 96:275-289.

Stocker M, Krause M, Pedarzani P (1999) An apamin-sensitive Ca2+activated $\mathrm{K}+$ current in hippocampal pyramidal neurons. Proc Natl Acad Sci USA 96:4662-4667.

Storm JF (1990) Potassium currents in hippocampal pyramidal cells. Prog Brain Res 83:161-187.

Stuart GJ, Dodt HU, Sakmann B (1993) Patch-clamp recordings from the soma and dendrites of neurons in brain slices using infrared video microscopy. Pflügers Arch 423:511-518.

Tanabe M, Gahwiler BH, Gerber U (1998) L-Type Ca2+ channels mediate the slow $\mathrm{Ca} 2+$-dependent afterhyperpolarization current in rat CA3 pyramidal cells in vitro. J Neurophysiol 80:2268-2273.

Thibault O, Landfield PW (1996) Increase in single L-type calcium channels in hippocampal neurons during aging. Science 272:1017-1020

Thibault O, Porter NM, Chen KC, Blalock EM, Kaminker PG, Clodfelter GV, Brewer LD, Landfield PW (1998) Calcium dysregulation in neuronal aging and Alzheimer's disease: history and new directions. Cell Calcium 24:417-433.

Thompson LT, Moyer Jr JR, Disterhoft JF (1996a) Trace eyeblink conditioning in rabbits demonstrates heterogeneity of learning ability both between and within age groups. Neurobiol Aging 17:619-629. 
Thompson LT, Moyer Jr JR, Disterhoft JF (1996b) Transient changes in excitability of rabbit CA3 neurons with a time course appropriate to support memory consolidation. J Neurophysiol 76:1836-1849.

Torres GE, Chaput Y, Andrade R (1995) Cyclic AMP and protein kinase A mediate 5-hydroxytryptamine type 4 receptor regulation of calcium-activated potassium current in adult hippocampal neurons. Mol Pharmacol 47:191-197.

Torres GE, Arfken CL, Andrade R (1996) 5-Hydroxytryptamine4 receptors reduce afterhyperpolarization in hippocampus by inhibiting calcium-induced calcium release. Mol Pharmacol 50:1316-1322.

Verkhratsky A, Toescu EC (1998) Calcium and neuronal aging. Trends Neurosci 21:2-7.
Weiss C, Preston AR, Oh MM, Schwarz RD, Welty D, Disterhoft JF (2000) The M1 muscarinic agonist CI-1017 facilitates trace eyeblink conditioning in aging rabbits and increases the excitability of CA1 pyramidal neurons. J Neurosci 20:783-790.

Zhang L, Weiner JL, Valiante TA, Velumian AA, Watson PL, Jahromi SS, Schertzer S, Pennefather P, Carlen PL (1994) Whole-cell recording of the $\mathrm{Ca}(2+)$-dependent slow afterhyperpolarization in hippocampal neurones: effects of internally applied anions. Pflügers Arch 426:247-253

Zhang L, Pennefather P, Velumian A, Tymianski M, Charlton M, Carlen PL (1995) Potentiation of a slow $\mathrm{Ca}(2+)$-dependent $\mathrm{K}+$ current by intracellular $\mathrm{Ca} 2+$ chelators in hippocampal CA1 neurons of rat brain slices. J Neurophysiol 74:2225-2241. 